\title{
LUNAR ILLUMINATION SHAPES SMALL MAMMAL ACTIVITY IN LOWLAND AGRICULTURAL LANDSCAPES
}

\author{
Luke Owen, Eleanor Smith, And Carl D. Soulsbury* \\ School of Life Sciences, University of Lincoln, Green Lane, Lincoln, LN6 7TS \\ *Corresponding author: csoulsbury@lincoln.ac.uk
}

\begin{abstract}
.
The behavioural patterns of small mammalian prey species have been shown to be widely impacted by predator avoidance. Cues to avoid predation may come from the predator itself or environmental cues, such as moonlight and available vegetative cover. We investigated how the activity of the bank vole Myodes glareolus, field vole Microtus agrestis, wood mouse Apodemus sylvaticus and the common shrew Sorex araneus were impacted by changes in habitat and lunar light conditions across a range of habitats (mainly grassland protected sites) in Lincolnshire (UK). Microhabitat vegetation density as well as weather conditions were recorded across all trap sites, with Longworth traps set overnight and the successfully captured species recorded the following morning. Overnight temperature was found to positively influence capture rate across all species. The lunar phase was found to significantly impact capture rate, with the gibbous lunar phase providing the highest capture rate across species. The interaction between illumination and vegetation density was also found to impact activity levels in the bank vole and wood mouse, with the bank vole showing higher activity in thick vegetation at low light levels and across habitats at higher light levels, whereas wood mice were more often captured in intermediate cover at low and intermediate illumination but across a range of habitats at brighter illumination. In combination, it suggests that small mammal activity is altered to potentially reduce predation risk. However, in this community at least, brighter lunar illumination leads to increase activity.
\end{abstract}

Key words: predator avoidance, illumination, temperature, small mammal, lunar cycle

\section{BACKGROUND}

A major force shaping prey behaviour is the avoidance of predators (Lima and Dill 1990). Predator avoidance can lead to changes in prey's activity duration, foraging tactics, and micro-habitat selection (Lima \& Dill 1990; Ferrari et al. 2009). Prey may use a variety of direct or indirect cues to assess the risk of predation. These cues may come from the predator directly or indirectly (e.g. scent marks, calls) or by using cues from the environment that may relate to heightened predation risk. For nocturnal animals, both predation risk of prey (Mougeot \& Bretagnolle 2000; Griffin et al. 2005) and foraging efficiency of predators (Packer et al. 2011) may cycle with lunar phase. As a consequence, many prey species schedule activity depending on the lunar phase.

Nocturnal species experience significant monthly fluctuations in ambient light levels, between moonless and full moon nights, as well as spatially due to light pollution (Spitschan et al. 2016). In response, both predator and prey may adjust their activity, movement and microhabitat use to track these changes (Penteriani et al. 2013). For example, many nocturnal species, including small mammals, that forage in relatively open habitats respond to moon- light by reducing activity outside their nests or burrows, and by shifting such activity towards areas of relatively dense cover (e.g. Lockard \& Owings 1974; Price et al. 1984; Bowers 1988; Wolfe \& Summerlin 1989; Kaufman \& Kaufman 1982; Upham \& Hafner 2013; Dell'Agnello et al. 2020; Mori et al. 2020). This reduction in activity due to brighter illumination from moonlight has been widely investigated as a potential cue for increased predation risk (Beier 2006; Caro 2005). This negative effect of moonlight on the activity patterns of small prey species is greatest in habitats with areas of little or sparse vegetation such as open grasslands (Prugh \& Golden 2013), as lower cover provided by vegetation affects the vulnerability to aerial predators (Díaz 1992; Longland \& Price 1991; Wilson 1992; Mazurkiewicz 1994). In turn, the hunting success of some predators may be increased on moonlit nights (e.g. barn owls: San-Jose et al. 2019). Not all studies however find that moonlight has a negative effect (Prugh \& Brashares 2010; Prugh $\&$ Golden 2014), and differences may arise between species based on predator detection mechanism.

Small rodents depend on the detection of a predator prior to actual contact. It is known that rodents use a range of differing cues for predation 
risk, including indirectly from predator odours (Navarro-Castilla \& Barja 2014) and directly via calls (Monarca et al. 2015). In response to increased exposure, rodents reduce their activity (Navarro-Castilla \& Barja 2014; Monarca et al. 2015). For nocturnal rodents, visual detection of predators is challenging; increased moonlight can for example, enhance visual detection of predators (Prugh \& Golden 2014), but also predator hunting success (San-Jose et al. 2019).

In this study, we examined whether the activity of a small mammal community was affected by moonlight conditions. The four species, the bank vole Myodes glareolus, field vole Microtus agrestis, wood mouse Apodemus sylvaticus and common shrew Sorex araneus are sympatric and share common predators (Wróbel \& Bogdziewicz 2015). There are between-study differences in reported activity periods; wood mice are predominantly nocturnal, where as banks voles can be active throughout the day, with peaks of activity at twilight (Miller \& Elton 1955; Brown 1956; Greenwood 1978; Halle \& Lehmann 1993). Field voles are much more active during the day time (Brown 1956; Halle \& Lehmann 1992) and the common shrew which is typically active throughout the day and night (Crowcroft 1954). In addition, voles and shrews are thought to use cover to avoid predators, whereas wood mice use agility to avoid predators; such patterns should therefore alter preferred microhabitat (Jensen \& Honess 1995). Thus, it might be expected that moonlight and microhabitat are key determinants of small rodent activity (Wróbel \& Bogdziewicz 2015). To test this, we carried out a small mammal trapping study and measured trapping rates across habitats and light lunar light conditions. We predicted that small mammal activity would be greater in dark nights, with greater captures in dense habitat in lighter nights.

\section{Material ANd Methods}

\section{Study sites}

Trapping occurred in various locations over Lincolnshire (UK), a largely agricultural county in eastern England (Fig. 1) from the $21^{\text {st }}$ July 2019 till the $16^{\text {th }}$ September 2019. A range of sites were included in the trapping period with a large number of grassland habitats (Mill Hill Quarry ( $\mathrm{N}$ traps $=13, \mathrm{~N}$ trap nights = 26); Candlesby Hill Quarry $(\mathrm{N}$ traps $=30, \mathrm{~N}$ trap nights $=60)$; Woodhall Spa Airfield $(\mathrm{N}$ traps $=$ $27, \mathrm{~N}$ trap nights $=54)$; Gibraltar Point $(\mathrm{N}$ traps $=50$, $\mathrm{N}$ trap nights $=100)$; Whisby Nature Park ( $\mathrm{N}$ traps
$=50, \mathrm{~N}$ trap nights $=100)$; Sotby Meadows $(\mathrm{N}$ traps $=27, \mathrm{~N}$ trap nights $=54)$; Saltfleetby-Theddlethorpe Dunes $(\mathrm{N}$ traps $=30, \mathrm{~N}$ trap nights $=60)$ ), as well as woodland (Sir Joseph Banks Country Park (N traps = $50, \mathrm{~N}$ trap nights $=100)$, Goslings Corner Wood $(\mathrm{N}$ traps $=30, \mathrm{~N}$ trap nights $=60)$; Moulton Marsh $(\mathrm{N}$ traps $=30, \mathrm{~N}$ trap nights $=60)$ ), reed heavy scrubland $($ Wolla Bank Pit $(\mathrm{N}$ traps $=27, \mathrm{~N}$ trap nights $=54)$; Boultham Mere $(\mathrm{N}$ traps $=47, \mathrm{~N}$ trap nights $=54)$; Tetney Blow Wells $(\mathrm{N}$ traps $=30, \mathrm{~N}$ trap nights $=60)$ ) and farmland (Leadenhall Farm ( $\mathrm{N}$ traps $=30, \mathrm{~N}$ trap nights $=60)$ ).

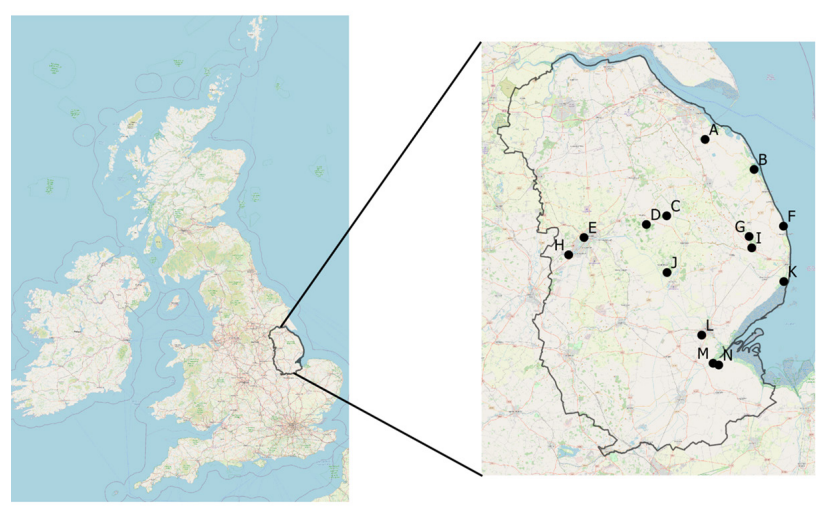

Figure 1: Map of the United Kingdom with an inset map showing trap sites in Lincolnshire: A-Tetney Blow Wells; B- Saltfleetby-Theddlethorpe Dunes; C- Sotby Meadows; D- Goslings Corner Wood; E- Boultham Mere; F- Wolla Bank Pit; G- Mill Hill Quarry; H- Whisby Nature Park; I- Candlesby Hill Quarry; J- Woodhall Spa Airfield; KGibraltar Point; L- Sir Joseph Banks Country Park; MMoulton Marsh; N- Leadenhall Farm.

\section{Trapping methodology}

Longworth traps were set individually at 5 or 10 metres intervals. Spacing could not be exact, as we needed to ensure that the trap position was safe e.g. not exposed, unlikely to be moved or disturbed, or prevent water ingress to traps, all to prevent potential animal welfare issues (Soulsbury et al. 2020). The majority of traps were set in a linear pattern $(\mathrm{N}=428)$, with a subset within sites placed in a grid fashion ( $\mathrm{N}=52$ traps), dependent on-site topography. The traps were set up before dusk and contained bedding (straw), mixed bird seeds, soaked carrot pieces and 10 grams of casters (pupated fly larvae). Each trap was set at an angle to prevent water, urine, and faecal matter from running into the nest chamber and onto the bedding and causing possible distress or discomfort for the trapped individual. To avoid potential problems from overheating the traps were placed out of direct sunlight. Surrounding vegetation was used 
to cover all traps to provide further insulation and reduce the risk of mortality from overnight weather conditions. Furthermore, if the overnight temperature dropped below the minimum required temperature $\left(5^{\circ} \mathrm{C}\right)$, then no trapping took place. The location of each of the traps was marked by a bamboo pole with coloured tape attached at the top to ensure that no traps were to be left unchecked or potentially lost.

The morning after, all the traps were checked in the order they were placed. If the trap was successful, the trapped individual within was removed using the polythene bag method and the species was recorded. The amount of time spent within the polythene bag and any handling of the small mammals was kept to a minimum to ensure minimal unnecessary distress. Individuals were released at the site of capture to further prevent distress. This process was repeated until all traps at each site were collected. Traps were then removed from the site during the day to ensure equipment was not lost or damaged, and no animals were trapped unintentionally. Trapping occurred for two nights at each location to ensure multiple trap sites were included each week and to reduce the potential of recapturing the same individuals. In total, there were 960 trap nights across all sites.

\section{Micro-Habitat and Weather Variables}

The habitat factors surrounding each trap were recorded within a $50 \mathrm{~cm}$ radius (microhabitat). For each trap, a visual estimate of vegetation density was also recorded, using an A4 chequered cardboard sheet divided into 10 equal squares; an estimate of the percentage of the sheet obscured by vegetation was made (Monamy \& Fox 2000). At each location, 4 measurements north, south, east and west of the trap location were taken and an average calculated for the microhabitat. The overnight weather conditions including temperature $\left({ }^{\circ} \mathrm{C}\right)$, lunar phase, and illumination from moonlight (\%) were recorded for each trap night and location (World Weather Online 2019).

\section{Statistical Methods}

Data was tested for normality using the Anderson-Darling normality test on Minitab 17 (Minitab, LLC, 2010) and, due to the significant departure from normality, the data collected for density was $\log$ transformed for analysis. We carried out binomial generalized linear mixed effects models (GLMM), first testing whether overall trapping success rate differed between traps set in a linear or grid fashion (e.g. Pearson \& Ruggerio 2003), but lack of model convergence meant we could not test this at a species level. We then carried out GLMMs testing lunar phase (crescent or gibbous) as a factor, with temperature as a covariate, and trap number as a nested random effect with trap location. Capture probability for each species (yes/no) were then tested. Following this, we then tested whether lunar illumination (\%), microhabitat density and their interaction effected capture probability. Temperature was again included as a covariate and trap number as a nested random effect with trap location. All analyses were carried out in $\mathrm{R}$ version 3.6.3 ( $\mathrm{R}$ Core Team 2020), using LMERTEST and LME4 (Bates et al. 2015; Kuznetsova et al. 2017). Post hoc tests of factors were compared using EMMEANS (Lenth 2020).

\section{RESULTS}

\section{Summary capture information}

In total, we caught 104 small mammals, which were predominantly bank voles and wood mice (Table 1). Overall average trap rates were $13.3 \%$ per night, with bank voles and wood mice being caught an average of $5.3 \%$ and $6.2 \%$ traps per night respectively. No mortality was recorded during the study period. Overall, there were no difference in capture rates of traps set in linear or grid patterns (GLMM: Estimate $+\mathrm{SE}=0.33+0.45, \mathrm{z}=-0.74, \mathrm{P}=0.458$ ).

Table 1: Summary capture statistics and mortality rates of small mammals in Longworth traps

\begin{tabular}{lccc}
\hline \multicolumn{1}{c}{ Species } & $\begin{array}{c}\mathbf{N} \\
\text { caught }\end{array}$ & $\begin{array}{c}\text { N } \\
\text { mortality } \\
(\%)\end{array}$ & $\begin{array}{c}\text { Average } \\
\text { nightly trap } \\
\text { rate (\%) }\end{array}$ \\
\hline Bank vole & 41 & 0 & $5.3 \%$ \\
Wood Mouse & 44 & 0 & $6.2 \%$ \\
Common shrew & 23 & 0 & $3.0 \%$ \\
Field Vole & 13 & 0 & $1.8 \%$ \\
\hline Total & 104 & 0 & $13.3 \%$ \\
\hline
\end{tabular}

\section{Activity in relation to moon phase}

For all species, temperature had a positive influence on capture rates (Table 2). In addition, lunar phase had a significant positive influence on capture rate (Table 2). Capture rates were greater in the gibbous lunar phase for all species (Fig. 2), but this effect was weakest in wood mice in comparison to other species (Fig. 2). 
Table 2: Trap success of the wood mouse, bank vole, field vole and common shrew in relation to temperature and lunar phase. Model outputs from binomial GLMMs for each species are shown. For each model variable, the estimate, standard error (SE), $\mathrm{z}$ value and $\mathrm{p}$ value are reported.

\begin{tabular}{llrrr}
\hline Model & Variables & Estimate \pm SE & Z value & P value \\
\hline Wood mouse & Temperature & $0.16 \pm 0.00$ & 48.15 & $<0.001$ \\
& Lunar phase (crescent/gibbous) & $0.04 \pm 0.00$ & 8.46 & $<0.001$ \\
\multirow{2}{*}{ Bank vole } & Temperature & $0.35 \pm 0.00$ & 89.71 & $<0.001$ \\
& Lunar phase (crescent/gibbous) & $3.04 \pm 0.53$ & 5.73 & $<0.001$ \\
\multirow{2}{*}{ Common shrew } & Temperature & $0.23 \pm 0.05$ & 4.47 & $<0.001$ \\
& Lunar phase (crescent/gibbous) & $1.59 \pm 0.05$ & 2.67 & $<0.001$ \\
\multirow{2}{*}{ Field vole } & Temperature & $0.07 \pm 0.01$ & 9.26 & $<0.001$ \\
& Lunar phase (crescent/gibbous) & $2.32 \pm 0.01$ & 294.47 & $<0.001$ \\
\hline
\end{tabular}

Table 3: Trap success of the wood mouse, bank vole, field vole and common shrew in relation to temperature, illumination, density and the combined effects of the latter .

\begin{tabular}{llrrr}
\hline Model & Variables & Estimate \pm SE & Z value & P value \\
Wood mouse & Temperature & $0.28 \pm 0.06$ & 48.15 & $<0.001$ \\
& Illumination & $-0.70 \pm 0.05$ & 8.46 & $<0.001$ \\
& Microhabitat thickness & $-0.50 \pm 0.05$ & -12.47 & $<0.001$ \\
& Illumination *microhabitat thickness & $0.01 \pm 0.00$ & 11.04 & $<0.001$ \\
\hline Bank vole & Temperature & $0.31 \pm 0.01$ & 70.71 & $<0.001$ \\
& Illumination & $0.15 \pm 0.00$ & 22.93 & $<0.001$ \\
& Microhabitat thickness & $0.10 \pm 0.00$ & 34.29 & $<0.001$ \\
Common shrew & Illumination *microhabitat thickness & $-0.00 \pm 0.00$ & -9.33 & $<0.001$ \\
& Temperature & $0.24 \pm 0.05$ & 4.37 & $<0.001$ \\
& Illumination & $0.02 \pm 0.02$ & 0.67 & 0.908 \\
& Microhabitat thickness & $-0.00 \pm 0.02$ & 0.12 & 0.503 \\
Field vole & Illumination *microhabitat thickness & $0.00 \pm 0.00$ & 0.57 & 0.569 \\
& Temperature & $0.09 \pm 0.07$ & 1.41 & 0.159 \\
& Illumination & $0.03 \pm 0.02$ & 1.36 & 0.174 \\
& Microhabitat thickness & $-0.00 \pm 0.02$ & -0.16 & 0.875 \\
\hline
\end{tabular}

\section{Activity in relation to micro-habitat and illumination}

For bank voles and wood mice, there were significant effects of temperature and the interaction between microhabitat thickness and illumination (Table 3). For bank voles, more captures were found in thicker habitats in low light levels, but captures were more evenly spread across habitats at high light levels (Fig. 3a). Wood mice were commonly found at intermediate density at low and medium illumination, but more across all habitats at bright illumination (Fig. 3b).

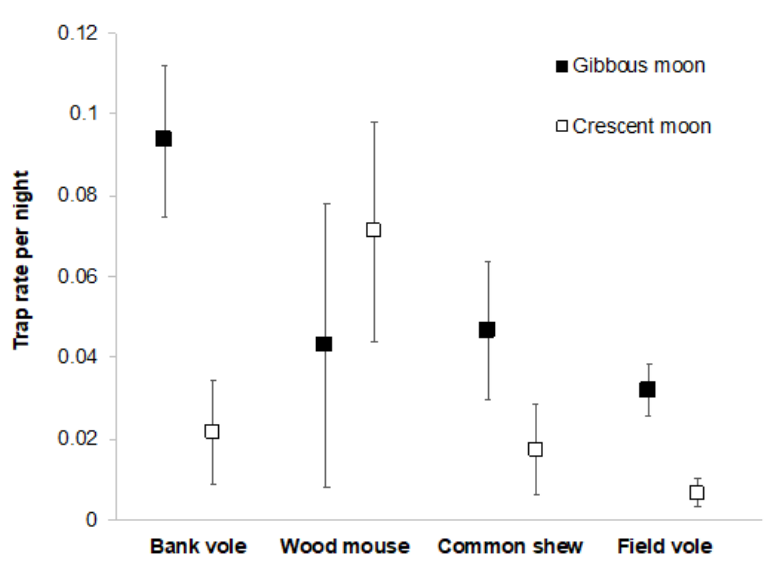

Figure 2: Mean \pm SE capture rates of small mammals in relation to either crescent or gibbous lunar phase. Differences between lunar phases are significant (see Table 2) for each species. 

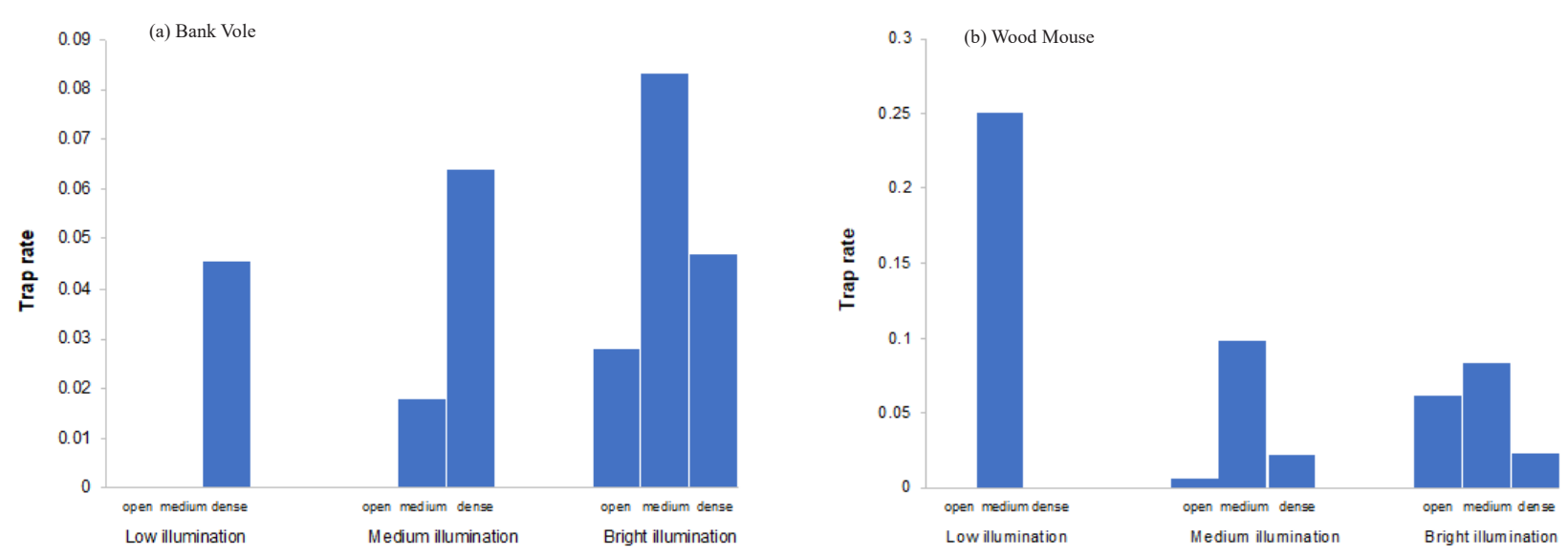

Figure 3: Overall trap rates (captures per trap) of (a) bank voles and (b) and wood mice, in relation to habitat density (open $=0-33 \%$, medium $=33-66 \%$, dense $=>66 \%$ ) and illumination $($ low $=0=33 \%$, medium $=33-66 \%$, bright $=>66 \%$ )

\section{Discussion}

This study highlights the importance of temperature, lunar phase and micro-habitat in shaping small mammal activity patterns. Contrary to our predictions, all species were positively affected by lunar phase, and two species with a greater nocturnal habit (wood mouse and bank vole) were most strongly affected by the interactive effects of lunar illumination and habitat selection, being found in denser microhabitat on dark nights. Our work highlights that lunar illumination and microhabitat must be considered in conjunction (Jacob et al. 2017; Mori et al. 2020). We also found a general positive effect of temperature on small mammal activity, something that has been widely reported (Prochaska \& Slade 1981; Vickery \& Bider 1981; Churchfield 1982; Wolton 1983; though see Wróbel \& Bogdziewicz 2015).

Across small mammals, the effect of moon phase and brightness seem to vary greatly, even within species. For example, bank voles have previously been shown to have a significantly higher capture rate with increased moonlight in beech Fagus sylvatica stands (Wróbel \& Bogdziewicz 2015). Bank voles are thought to prefer dense vegetation (Plesner Jensen \& Honess 1995); similarly, we found that capture rates were higher in general in dense vegetation, but captures were only found in short vegetation under bright moonlight. Bank voles are more active throughout the day and with peaks of activity at dawn and dusk (e.g. Greenwood 1978), and bank voles are important parts of the diet of diurnal predators such as kestrels Falco tinnunculus (Shrubb 1980). Increased activity during moonlit nights may reflect a reduction in diurnal activity and therefore reduced day-time predation risk. For wood mice, we found that differences between lunar phases were small, but the microhabitat was again important. In low illumination nights, wood mice were more active in intermediately dense habitats, whereas they were equally active in all habitats in bright moon illumination. A negative effect of illumination on wood mice has been observed (Wolton 1983), and being in the open on brightly illuminated nights has been seen to reduce wood mouse activity (Plesner et al. 1995), but other studies have found no effect (Díaz et al. 2005). We found that wood mice preferred denser habitats, but were more often found in denser habitats on dark nights. Activity of field voles or common shrews showed no relationship between illumination and habitat, though both were caught more often on bright moon phases.

The results showing a positive influence of moon phase on rodent activity is surprising. Barn owls Tyto alba are common predators in our study area and their hunting success is greatest in bright moonlight (San Jose et al. 2019). However, visual acuity of prey may also be increased, suggesting more complex influences of moon light on prey behaviour (Prugh \& Golden 2014). In addition, prey may be balancing nocturnal activity in bright moonlight in comparison to predation risk from daylight predators e.g. kestrels. Whilst we measured local microhabitat density, there may be a varying effect at different scalars, e.g. distance to cover, that may be important. Irrespective, the assumption that moonlight suppresses small mammal activity is clearly not always the case.

\section{Conclusion}

To conclude, it is clear that weather and habitat factors have a significant impact on activity in small mammals. We found that temperature and bright lunar phases positively influence activity, and for bank 
voles and wood mice, this effect was modified by micro-habitat structure.

\section{ACKNOWLEDGEMENTS}

We would like to thank Dave Bromwich, Head of Nature Reserves at the Lincolnshire Wildlife Trust, for granting permission to trap at all locations as well as the wardens who granted permission to trap at each Lincolnshire Wildlife Trust Nature Reserve including: Matt Blissett, Sophie Hawkridge, Grahame Hopwood, Dave Miller, Kevin James, Kevin Wilson and John Oliver. We would also like to thank Ian Willoughby for granting permission to trap at Leadenhall Farm and Adrian Isaac for giving permission to work at Sir Joseph Banks Country Park. Finally, we would like to thank Natural England for granting permission to work on all SSSIs and to Tammy Smalley and Clare Sterling at Lincolnshire Wildlife Trust for their help facilitating this project. The manuscript greatly benefitted from comments from Emiliano Mori and two anonymous reviewers.

\section{REFERENCES}

Bates, D., Maechler, M., Bolker, B. \& Walker, S. (2015) Fitting Linear Mixed-Effects Models Using lme4. J. Stat Soft. 67, 1-48.

Beier, P. (2006) Effects of artificial night lighting on terrestrial mammals. In: Ecological Consequences of Artificial Night Lighting. Washington, D.C.: Island Press., pp. 19-42.

Bowers, M.A. (1988) Seed removal experiments on Desert Rodents: The microhabitat by moonlight effect. J. Mammal. 69, 201-204. doi: 10.2307/1381778

Brown, L.E. (1956) Field experiments on the activity of small mammals, Apodemus, Clethrionomys and Microtus. Proc. Zool Soc. Lond. 126, 549-564. doi:10.1111/j.1096-3642.1956.tb00452.x

Caro, T. (2005) Antipredator Defenses in Birds and Mammals. Chicago, Illinois: University of Chicago Press. pp. 1-592.

Churchfield, S. (1982) The influence of temperature on the activity and food consumption of the common shrew. Acta Theriol. 27, 295-304.

Crowcroft, P. (1954) The daily cycle of activity in British shrews. Proc. Zool Soc. Lond. 123, 715-730. doi:/10.1111/j.1096-3642.1954.tb00197.x

Dell'Agnello, F., Martini, M., Mori, E., Mazza, G., Mazza, V. \& Zaccaroni, M. (2020) Winter activity rhythms of a rodent pest species in agricultural habitats. Mamm. Res. 65, 69-74. doi:10.1007/s13364-019-00443-4
Díaz, M. (1992) Rodent seed predation in cereal crop areas of central Spain: effects of physiognomy, food availability, and predation risk. Ecog. 15, 77-85. doi:10.1111/j.1600-0587.1992.tb00011.x

Díaz, M., Torre, I., Peris, A. \&Tena, L. (2005) Foraging behavior of wood mice as related to presence and activity of genets. J. Mammal. 86, 1178-1185. doi:10.1644/04-MAMM-A-127R1.1

Ferrari, M.C.O., Sih, A. \& Chivers, D.P. (2009) The paradox of risk allocation: a review and prospectus. Anim. Behav. 78, 579-585. doi:10.1016/j.anbehav.2009.05.034

Griffin, P.C., Griffin, S.C., Waroquiers, C. \& Mills, L.S. (2005) Mortality by moonlight: predation risk and the snowshoe hare. Behav. Ecol. 16, 938-944. doi:10.1093/beheco/ari074

Greenwood, P.J. (1978) Timing of activity of the bank vole Clethrionomys glareolus and the wood mouse Apodemus sylvaticus in a deciduous woodland. Oikos, 31, 123-127.

Halle, S. \& Lehmann, U. (1992) Cycle-correlated changes in the activity behaviour of field voles, Microtus agrestis. Oikos. 64, 489-497. doi:10.2307/3543393

Jacob, S.A., Matter, S.F. \& Cameron, G.N. (2017) Interactive effects of vegetation and illumination on foraging behavior of white-footed mice (Peromyscus leucopus). J. Mammal. 98, 804-814. doi:10.1093/jmam$\mathrm{mal} / \mathrm{gyx} 012$

Kaufman, D.W. \& Kaufman, G.A. (1982) Effect of moonlight on activity and microhabitat use by Ord's kangaroo rat (Dipodomys ordit). J. Mammal. 63, 309-312. doi: 10.2307/1380644

Kuznetsova, A., Brockhoff, P.B. \& Christensen, R.H.B. (2017) lmerTest Package: Tests in Linear Mixed Effects Models. J. Stat. Soft. 82, 1-26.

Lenth, R. (2020) emmeans: Estimated Marginal Means, aka Least-Squares Means. R package version 1.4.5. https://CRAN.R-project.org/package=emmeans

Lima, S. \& Dill, L. (1990) Behavioural decisions made under the risk of predation: a review and prospectus. Can. J. Zool. 68, 619-640.

Lockard, R.B. \& Owings, D.H. (1974) Seasonal variation in moonlight avoidance by bannertail kangaroo rats. J. Mammal. 55, 189-193. doi:10.1139/z90-092

Longland, W.S. \& Price, M.V. (1991) Direct observations of Owls and Heteromyid Rodents: Can predation risk explain microhabitat use? Ecol. 72, 2261-2273. doi: $10.2307 / 1379266$

Mazurkiewicz, M. (1994) Factors influencing the distribution of the bank vole in forest habitats. Acta Theriol. $39,113-126$. 
Miller, R.S. \& Elton, C. (1955) Activity rhythms in the Wood Mouse, Apodemus sylvaticus and the Bank Vole, Clethrionomys glareolus. Proc. Zool Soc. Lond. 12, 505-519. doi:10.1111/j.1096-3642.1955. tb00613.x

Minitab, LLC (2010) Minitab 17 [Statistical software]. State College, Pennsylvania: Minitab, LLC. Available from https://minitab.com/en-us/

Monamy, V. \& Fox, B.J. (2000) Small mammal succession is determined by vegetation density rather than time elapsed since disturbance. Austral Ecol. 25, 580-587. doi:10.1111/j.1442-9993.2000.tb00063.x

Monarca, R.I., Mathias, M.D.L. \& Speakman, J.R. (2015) Behavioural and physiological responses of wood mice (Apodemus sylvaticus) to experimental manipulations of predation and starvation risk. Phys \& Behav. 149, 331-339. doi:10.1016/j.physbeh.2015.06.037

Mori, E., Sangiovanni, G. \& Corlatti, L. (2020) Gimme shelter: The effect of rocks and moonlight on occupancy and activity pattern of an endangered rodent, the garden dormouse Eliomys quercinus. Behav. Proc. 170, 103999. doi:10.1016/j.beproc.2019.103999

Mougeot, F. \& Bretagnolle, V. (2000) Predation risk and moonlight avoidance in nocturnal seabirds. $\mathrm{J}$ Avian Biol. 31, 376-386. doi: 10.1034/j.1600048X.2000.310314.X

Navarro-Castilla, Á. \& Barja, I. (2014) Does predation risk, through moon phase and predator cues, modulate food intake, antipredatory and physiological responses in wood mice (Apodemus sylvaticus)? Behav. Ecol. Sociobiol. 68, 1505-1512. doi:10.1007/s00265-0141759-y

Packer, C., Swanson, A., Ikanda, D. \& Kushnir, H. (2011) Fear of darkness, the full moon and the nocturnal ecology of African lions. PloS One. 6, e22285. doi 10.1371/journal.pone.0022285

Pearson, D.E. \& Ruggiero, L.F. (2003) Transect versus grid trapping arrangements for sampling small-mammal communities. Wild. Soc. Bull., 454-459.

Penteriani, V., Kuparinen, A., del Mar Delgado, M., Palomares, F., López-Bao, J.V., Fedriani, J.M., Calzada, J., Moreno, S., Villafuerte, R., Campioni, L. \& Lourenço, R. (2013) Responses of a top and a meso predator and their prey to moon phases. Oecol. 173, 753766. doi: 10.1007/s00442-013-2651-6

Plesner Jensen, S. \& Honess, P. (1995) The influence of moonlight on vegetation height preference and trappability of small mammals. Mammal. 59, 35-42.

Price, M.V., Waser, N.M. \& Bass, T.A. (1984) Effects of moonlight on microhabitat use by desert rodents. J. Mammal. 65, 353-356. doi: 10.2307/1381183
Prochaska, M.L. \& Slade, N.A. (1981) The effect of Sigmodon hispidus on summer diel activity patterns of Microtus ochrogaster .Kansas. Trans. Kans. Acad. Sci. 84, 134-138. doi: 10.2307/3628304

Prugh, L.R.\& Brashares, J. (2010) Basking in the moonlight? Effect of illumination on capture success of the endangered giant kangaroo rat. J. Mammal. 91, 12051212. doi:10.1644/10-MAMM-A-011.1

Prugh, L.R. \& Golden, C.D. (2014) Does moonlight increase predation risk? Meta-analysis reveals divergent responses of nocturnal mammals to lunar cycles. J Anim. Ecol. 83, 504-514. doi:10.1111/13652656.12148

R Core Team. (2020) R: A language and environment for statistical computing. R Foundation for Statistical Computing, Vienna, Austria. URL https://www.R-project.org/.

San-Jose, L., Séchaud, R., Schalcher, K., Judes, C., Questiaux, A., Oliveira-Xavier, A., Gémard, C., Almasi, B, Béziers, P., Kelber, A., Amar, A. \& Roulin, A. (2019) Differential fitness effect of moonlight on plumage colour morphs in barn owls. Nature Ecol Evol. 3, 1331-1340. doi:10.1038/s41559-019-0967-2

Shrubb, M. (1980) Farming influences on the food and hunting of kestrels. Bird Study 27, 109-115. doi: 10.1080/00063658009476666

Soulsbury, C.D., Gray, H.E., Smith, L.M., Braithwaite, V., Cotter, S.C., Elwood, R.W., Wilkinson, A. \& Collins, L.M. (2020) The welfare and ethics of research involving wild animals: A primer. Methods in Ecology and Evolution, 11, 1164-1181. doi: 10.1111/2041210X.13435

Spitschan, M., Aguirre, G.K., Brainard, D.H. \& Sweeney, A.M. (2016) Variation of outdoor illumination as a function of solar elevation and light pollution. Sci Reports. 6, e26756. doi: 10.1038/srep26756

Upham, N. \& Hafner, J. (2013) Do nocturnal rodents in the Great Basin Desert avoid moonlight? J. Mammal. 94, 59-72. doi: 10.1644/12-MAMM-A-076.1

Vickery, W.L. \& Bider, J.R. (1981) The influence of weather on rodent activity. J. Mammal. 62, 140-145. doi: $10.2307 / 1380484$

Wilson, W.L. (1992) Behavioral ecology and population regulation of the wood mouse (Apodemus sylvaticus). $\mathrm{PhD}$ thesis. Queen's University: Belfast.

Wolfe, J.H. \& Summerlin, C.T. (1989) The influence of lunar light on nocturnal activity of the old-field mouse. Anim. Behav. 37, 410-414. doi: 10.1016/00033472(89)90088-2

Wolton, R. (1983) The activity of free-ranging wood mice Apodemus sylvaticus. J. Anim. Ecol. 52, 781-794. doi: $10.2307 / 4453$ 
World weather online (2019) World weather. Available from https://www.worldweatheronline.com [accessed 21 July 2019].

Wróbel, A., Bogdziewicz, M. (2015) It is raining mice and voles: which weather conditions influence the activity of Apodemus flavicollis and Myodes glareolus? Euro. J. Wild. Res. 61, 475-478. doi: 10.1007/s10344-0140892-2 